\title{
Hubungan Kejadian Anemia dengan Penyakit Ginjal Kronik pada Pasien yang Dirawat di Bagian IImu Penyakit Dalam RSUP dr M Djamil Padang Tahun 2010.
}

\author{
Rahmat Hidayat ${ }^{1}$, Syaiful Azmi ${ }^{2}$, Dian Pertiwi ${ }^{3}$
}

\begin{abstract}
Abstrak
Anemia merupakan salah satu masalah utama pada pasien penyakit ginjal kronik. Tinggi rendahnya laju filtrasi glomerulus mempengaruhi kejadian anemia pada penyakit ginjal kronik. Tujuan penelitian ini adalah mengidentifikasi hubungan kejadian anemia dengan penyakit ginjal kronik pada pasien yang dirawat di Bagian Penyakit Dalam tahun 2010. Penelitian yang dilakukan merupakan survei analitik dengan menggunakan design penelitian cross sectional study. Penelitian menggunakan data sekunder yang diambil dari sub bagian Rekam Medik (Medical Record) RSUP dr. M Djamil Padang dari Juni-Desember 2012 dengan jumlah sampel adalah 67 pasien penyakit ginjal kronik. Ditemukan angka kejadian anemia pada pasien penyakit ginjal kronik sebesar 98,5\% dengan rata-rata kadar $\mathrm{Hb}$ sebesar 7,3 g/dl dan rata-rata laju filtrasi glomerulus adalah $8,81 \mathrm{ml} / \mathrm{menit} / 1.73 \mathrm{~m} 2$. Dari hasil uji korelasi Pearson diperoleh hasil adanya hubungan kejadian anemia dengan penyakit ginjal kronik di RSUP dr M Djamil Padang dengan $p=0,00$ ( $p<$ 0,05). Kesimpulan hasil penelitian ini adalah semakin rendah laju filtrasi glomerulus menunjukkan semakin rendah juga kadar hemoglobin pada pasien penyakit ginjal kronik.
\end{abstract}

Kata kunci: anemia, penyakit ginjal kronik, laju filtrasi glomerulus

\begin{abstract}
Anemia is one of the major problems in patients with chronic kidney disease. High and low glomerular filtration rate affect the incidence of anemia in chronic kidney disease. The objective of this study was to identify the relationship of anemia on patients with chronic kidney disease in the Internal Medicine. The type of this research was analytic studies using a cross sectional study research design from June-December 2012 . This study used secondary data taken from Medical Record department of dr. M. Djamil hospital with samples of the entire medical record is 67 persons chronic kidney disease patients in 2010. The result found the incidence of anemia in chronic kidney disease patients was $98.5 \%$, with an average hemoglobin level at $7.3 \mathrm{~g} / \mathrm{dl}$ and mean glomerular filtration rate was $8.81 \mathrm{ml}$ $/ \mathrm{min} / 1.73 \mathrm{~m} 2$. Pearson correlation of test results obtained by the result of the relationship of anemia on patients with chronic kidney disease at dr M Djamil Padang Hospital with $p=0.00(p<0,05)$. The low rate of glomerular filtration rate also showed by the low level of hemoglobin in patients with chronic kidney disease
\end{abstract}

Keywords: anemia, chronic kidney disease, glomerular filtration rate

Affiliasi penulis: 1. Prodi Profesi Dokter FK UNAND (Fakultas Kedokteran Universitas Andalas Padang), 2. Bagian Penyakit Dalam FK UNAND 3. Bagian Patologi Klinik FK UNAND
Korespondensi: Rahmat Hidayat, Email: Rhmathidayat.rh@gmail.com, Telp: 081394846527 


\section{PENDAHULUAN}

Penyakit Ginjal Kronik (PGK) merupakan salah satu permasalahan di bidang nefrologi dengan angka kejadian yang masih cukup tinggi serta memiliki etiologi yang cukup luas dan

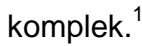

Derajat PGK berdasarkan laju fitrasi glomerulus (LFG) sesuai dengan rekomendasi NKF-DOQI (2002) dapat dilihat pada Tabel 1.

Tabel 1. Derajat penyakit ginjal kronik ${ }^{1}$

\begin{tabular}{clc}
\hline Stadium & \multicolumn{1}{c}{ Deskripsi } & LFG \\
\hline I & $\begin{array}{l}\text { Kerusakan ginjal disertai } \\
\text { LFG normal atau meninggi }\end{array}$ & $\geq 90$ \\
II & $\begin{array}{l}\text { Kerusakan ginjal disertai } \\
\text { penurunan ringan LFG }\end{array}$ & $60-89$ \\
& Penurunan moderat LFG & $30-59$ \\
III & Penurunan berat LFG & $15-29$ \\
IV & Gagal ginjal & $<15$ \\
V &
\end{tabular}

Prevalensi PGK pada tahun 2009, dengan batasan nilai laju filtrasi glomerulus kurang dari 60 $\mathrm{ml} / \mathrm{menit} / 1,73 \mathrm{~m}^{2}$, dilaporkan bervariasi yaitu sebesar $20 \%$ di Jepang dan di Amerika Serikat, $6,4 \%$ sampai $9,8 \%$ di Taiwan, 2,6\% sampai $13,5 \%$ di Cina, $17,7 \%$ di Singapura, dan $1,6 \%$ sampai $9,1 \%$ di Thailand. Survei komunitas yang dilakukan oleh Perhimpunan Nefrologi Indonesia menunjukkan bahwa $12,5 \%$ populasi sudah mengalami penurunan fungsi ginjal. ${ }^{2}$

Penurunan faal ginjal terjadi akibat berkurangnya unit struktural ginjal (nefron) yang masih berfungsi dengan baik. Hal ini akan menyebabkan bertambahnya beban pada nefron yang masih berfungsi baik dan secara bertahap akan menyebabkan kerusakan nefron yang masih tersisa tersebut serta mempercepat progresivitas kerusakan ginjal. ${ }^{3}$ Penurunan fungsi ginjal dapat diketahui dengan cara menghitung nilai laju filtrasi glomerulus melalui rumus Cockcroft-Gault atau MDRD (Modification of Diet in Renal Disease). ${ }^{4}$
PGK pada umumnya bersifat progresif. Hal ini berarti bahwa pada saat tertentu fungsi ginjal akan terus menurun sampai pada tahap akhir (the point of no return). ${ }^{2}$ Progresivitas penyakit ini akan terus berlanjut meskipun lesi yang mengawali proses terjadinya kerusakan ginjal tersebut dihilangkan. PGK ini pun biasanya disertai dengan berbagai komplikasi, seperti penyakit kardio vaskuler, penyakit saluran nafas, penyakit saluran cerna, kelainan di tulang dan otot, serta anemia. ${ }^{5}$

Kerusakan struktur dan fungsi ginjal bisa disertai dengan penurunan LFG. Penurunan laju fitrasi glomerulus ini berhubungan dengan gambaran klinik yang akan ditemukan pada pasien. Salah satunya adalah penurunan kadar hemoglobin atau hematokrit di dalam darah yang dapat dikatakan sebagai anemia. ${ }^{6}$

Anemia terjadi pada $80-90 \%$ pasien PGK, terutama bila sudah mencapai stadium III. Anemia terutama disebabkan oleh defisiensi Erythropoietic Stimulating Factors (ESF). ${ }^{7}$ Dalam keadaan normal $90 \%$ eritropoeitin (EPO) dihasilkan di ginjal tepatnya oleh juxtaglomerulus dan hanya $10 \%$ yang diproduksi di hati. Eritropoetin mempengaruhi produksi eritrosit dengan merangsang proliferasi, diferensiasi dan maturasi prekursor eritroid. Keadaan anemia terjadi karena defisiensi eritropoietin yang dihasilkan oleh sel peritubular sebagai respon hipoksia local akibat pengurangan parenkim ginjal fungsional. ${ }^{8}$ Respon tubuh yang normal terhadap keadaan anemia adalah merangsang fibroblas peritubular ginjal untuk meningkatkan produksi EPO, yang mana EPO dapat meningkat lebih dari 100 kali dari nilai normal bila hematokrit dibawah 20\%. Pada pasien PGK, respon ini terganggu sehingga terjadilah anemia dengan konsentrasi EPO yang rendah, dimana hal ini dikaitkan dengan defisiensi eritropoietin pada PGK. Faktor lain yang dapat menyebabkan anemia pada PGK adalah defisiensi besi, defisiensi vitamin, penurunan masa hidup eritrosit yang mengalami hemolisis, dan akibat perdarahan. ${ }^{1}$ 
Anemia merupakan komplikasi penyakit ginjal kronik yang sering terjadi, bahkan dapat terjadi lebih awal dibandingkan komplikasi PGK lainnya dan hampir pada semua pasien penyakit ginjal tahap akhir. Anemia sendiri juga dapat meningkatkan risiko morbiditas dan mortalitas secara bermakna dari PGK. ${ }^{9}$ Adanya anemia pada pasien dengan PGK dapat dipakai sebagai prediktor risiko terjadinya kejadian kardiovaskular dan prognosis dari penyakit ginjal sendiri. ${ }^{10}$

Pengelolaan penyakit ginjal kronik selama ini, lebih mengutamakan diagnosis dan pengobatan terhadap penyakit ginjal spesifik yang merupakan penyebab penyakit ginjal kronik serta dialisis atau transplantasi ginjal jika sudah terjadi gagal ginjal. Komplikasi yang sering terjadi pada penyakit ginjal kronik, seperti anemia perlu penatalaksanaan. Oleh karena itu, dalam tata laksana PGK perlu dilakukan pencegahan, perbaikan dan pengobatan terhadap anemia. ${ }^{7}$

Kejadian anemia pada PGK sering terjadi. Menurut Kidney Early Evaluation Program (KEEP) and National Health and Nutrition Examination Survey (NHANES) 1999-2004 didapatkan prevalensi kejadian anemia pada PGK sekitar $73,8 \% .{ }^{11} \mathrm{Hal}$ tersebut mendorong untuk mengetahui lebih lanjut apakah terdapat hubungan kejadian anemia dengan PGK pada pasien yang dirawat di bangsal penyakit dalam RSUP dr M Djamil Padang tahun 2010.

\section{METODE}

Penelitian dilakukan di Sub Bagian Rekam Medik (Medical Record) RSUP dr M Djamil Padang pada Juni sampai Desember 2012. Sampel dalam penelitian ini adalah seluruh penderita penyakit ginjal kronik yang dirawat di bagian ilmu penyakit dalam tahun 2010 yang memenuhi kriteria inklusi dan eksklusi yaitu sebanyak 67 orang. Metode pengambilan sampelnya adalah mencatat hasil pemeriksaan laboratorium pertama pada pasien penyakit ginjal kronik.Instrument penelitian yang digunakan adalah rekam medik seluruh pasien penyakit ginjal kronik yang dirawat di bagian ilmu penyakit dalam tahun 2010 dan Check list data yang diperlukan. Analisis hasil penelitian digunakan uji korelasi Pearson dengan tingkat pemaknaan $p<$ 0,05 .

\section{HASIL DAN PEMBAHASAN}

Pada Tabel 2 dapat dilihat bahwa kebanyakan pasien sudah memasuki stadium akhir penyakit ginjal kronik atau stadium 5 sebanyak 57 orang $(85,1 \%)$ sedangkan pasien PGK stadium III hanya sebanyak 3 orang $(4,5 \%)$.

Tabel 2. Distribusi frekuensi subjek penelitian berdasarkan derajat PGK

\begin{tabular}{ccc}
\hline Derajat PGK & Frekuensi & Persentase \\
\hline Stadium III & 3 & 4,5 \\
Stadium IV & 7 & 10,4 \\
Stadium V & 57 & 85,1 \\
Total & 67 & 100 \\
\hline
\end{tabular}

Laju filtrasi glomerulus terendah pada pasien PGK sebesar 1,84 ml/menit/1.73m2 dan tertinggi adalah $34,77 \mathrm{ml} / \mathrm{menit} / 1.73 \mathrm{~m} 2$. Rata-rata laju filtrasi glomerulus pasien PGK adalah 8,81 $\mathrm{ml} / \mathrm{menit} / 1.73 \mathrm{~m} 2$. Laju filtrasi glomerulus (LFG) merupakan indikator yang dapat digunakan untuk mengetahui derajat penyakit ginjal kronik. ${ }^{1}$ Penentuan derajat penyakit ginjal kronik berdasarkan LFG sesuai dengan rekomendasi NKF-DOQI (2002) yang dibagi menjadi 5 stadium. Dari hasil penelitian sebagian besar pasien yang dirawat sudah memasuki stadium akhir penyakit ginjal kronik atau stadium 5 sebanyak 57 orang $(85,1 \%)$ sedangkan pasien PGK stadium III hanya sebanyak 3 orang (4,5\%). Sebenarnya didalam populasi umum pasien PGK dengan stadium I dan II merupakan pasien yang paling banyak, namun pasien tersebut tidak menunjukkan gejala klinik/ asimtomatik. Hal ini berbeda bila pasien PGK sudah memasuki stadium akhir dimana gejala komplikasi sudah banyak bermunculan sehingga dibutuhkan penatalaksanaan lebih lanjut dan intensif di rumah 
sakit. Pasien PGK stadium 5 inilah yang paling banyak dirawat di Bagian Penyakit Dalam RSUP Dr M Djamil Padang.

Tabel 3. Prevalensi anemia pada pasien penyakit ginjal kronik

\begin{tabular}{ccc}
\hline Pasien PGK & Frekuensi & Persentase (\%) \\
\hline Anemia & 66 & 98,5 \\
Tidak anemia & 1 & 1,5 \\
Total & 67 & 100 \\
\hline
\end{tabular}

Pada Tabel 3 dapat dilihat bahwa prevalensi anemia pada pasien penyakit ginjal kronik adalah sebanyak 66 orang (98,5\%) sedangkan pasien penyakit ginjal kronik yang tidak menderita anemia sebanyak 1 orang (1,5\%). Anemia merupakan masalah medik yang paling sering dijumpai di klinik di seluruh dunia. Anemia bukanlah suatu kesatuan penyakit tersendiri (disease entity), tetapi adalah merupakan gejala berbagai macam penyakit dasar (underlying disease), oleh karena itu diagnosis anemia tidaklah cukup hanya sampai kepada label anemia tetapi harus dapat ditetapkan penyakit dasar yang menyebabkan anemia tersebut. Seperti halnya kejadian anemia pada penyakit ginjal kronik. Kadar hemoglobin merupakan salah satu indikator yang dapat digunakan untuk menunjukkan penurunan massa eritrosit (anemia). World Health Organization (WHO) merekomendasikan kadar $\mathrm{Hb}$ yang masuk kriteria anemia adalah laki-laki dewasa $<13 \mathrm{~g} / \mathrm{dl}$, wanita dewasa tidak hamil < $12 \mathrm{~g} / \mathrm{dl}$, wanita hamil $<11 \mathrm{~g} / \mathrm{dl}^{12}$

Kadar hemoglobin pada pasien penyakit ginjal kronik ini sudah masuk dalam kriteria anemia. Kadar hemoglobin terendah adalah sebesar 3,4 g/dl dan tertinggi sebesar $12,3 \mathrm{~g} / \mathrm{dl}$. Rata-rata kadar hemoglobin pasien yang menderita penyakit ginjal kronik pada penelitian adalah sebesar $7,3 \mathrm{~g} / \mathrm{dl}$. Hal ini sesuai dengan angka kejadian anemia yang lebih dari $85 \%$ pada penderita penyakit ginjal terutama bila sudah mencapai stadium 3 .

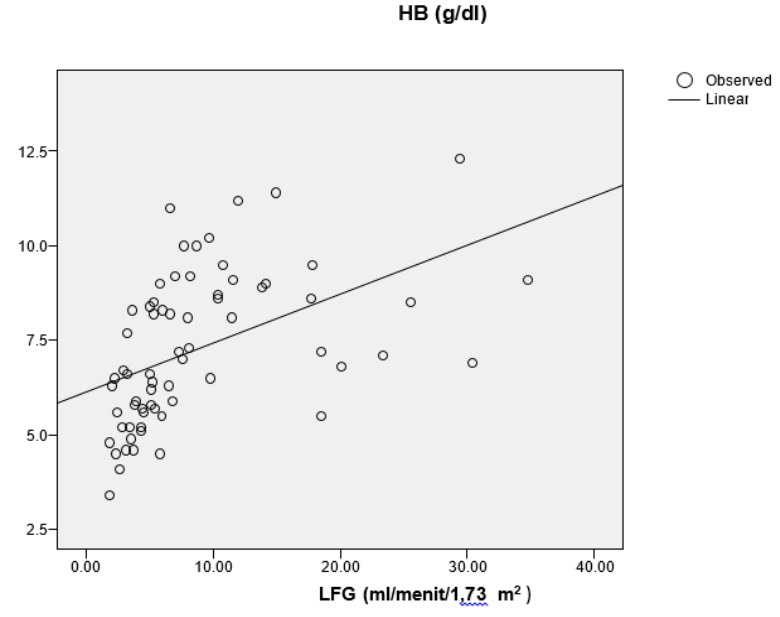

Gambar 1. Hubungan kadar hemoglobin dengan laju filtrasi glomerulus

Gambar diatas dapat disimpulkan bahwa semakin kecil laju filtrasi glomerulus pasien penyakit ginjal kronik maka kadar hemoglobin pada pasien tersebut semakin rendah. Untuk mengetahui hubungan kejadian anemia pada pasien penyakit ginjal kronik yang berdasarkan LFG dipergunakan analisis bivariat dengan menggunakan uji korelasi Pearson

Pada hasil penelitian ini didapatkan nilai koefisien korelasi Pearson ( $r$ ) sebesar 0,480, yang menunjukkan derajat hubungan yang sedang dengan tarif signifikansi $p=0,00(p>0,05)$. Hasil analisis uji statistik dapat disimpulkan bahwa terdapat hubungan yang signifikan antara kejadian anemia dengan derajat penyakit ginjal kronik pada pasien yang dirawat di bagian penyakit dalam RSUP dr M Djamil Padang tahun 2010. Anemia pada PGK sebagian besar ditandai dengan morfologi normositik normokrom, setelah disingkirkan kemungkinan anemia karena sebab lain seperti anemia karena hemodialisis, kekurangan zat besi, asam folat, atau vitamin B12, dan keganasan ${ }^{1}$. Anemia pada penyakit ginjal kronik disebabkan oleh multi faktor, tetapi sebagian besar berhubungan dengan defisiensi erythropoietic stimulating factor (ESF). Hal lain yang ikut berperan 
terjadinya anemia adalah gangguan eritropoiesis defisiensi besi, masa hidup eritrosit yang pendek akibat terjadinya hemolisis, defisiensi asam folat, perdarahan saluran cerna atau uterus, toksin azotemia, hemodialisis. ${ }^{13}$

\section{KESIMPULAN}

Ditemukan adanya hubungan kejadian anemia dengan penyakit ginjal kronik pada pasien yang dirawat di bagian penyakit dalam RSUP dr M Djamil Padang tahun 2010.

\section{DAFTAR PUSTAKA}

1. Sukandar E. Nefrologi klinik. Edisi ke-3, Bandung: Fakultas Kedokteran Universitas Padjadjaran; 2006.

2. Susalit E. Diagnosis dini penyakit ginjal kronik. Jakarta: Jurnal Penyakit Dalam. 2009. hlm.9-12.

3. Suwitra K. Buku ajar ilmu penyakit dalam jilid 2. Edisi ke-5. Jakarta: Interna Publishing. 2009. hlm.1035-40.

4. Widiana IGR. Distribusi geografis penyakit ginjal kronik di Bali: komparasi formula Cockcroftgault dan formula modification of diet in renal disease. J Peny Dalam. 2007;8(3):198-204.

5. Widiana IGR. Restriksi protein dan progresifitas penyakit ginjal kronik. Jakarta: Jurnal penyakit Dalam. 2009 22-25.

6. Suwitra K, Pendekatan diagnostik penyakit ginjal kronik. Jakarta : Jurnal Penyakit Dalam. 2009. hlm.14-21.
7. Suhardjono, Kelainan kardiovaskular pada penyakit ginjal kronik. Jakarta: Jurnal Penyakit Dalam. 2009. hlm.35-9.

8. National Kidney Foundation (NKF) Kidney Disease Outcome Quality Initiative (K/DOQI). Advisory Board: K/DOQI clinical practice guideline for chronic kidney disease: evaluation, classification, and stratification. Kidney Disease Outcome Quality Initiative. America Journal of Kidney Disease. 2002;17:S19-S28.

9. Macdougal IC, Walker R, Provenzano R, Alvaro F, Locay HR, Nader PC, et al. Corrects anemia in patients with chronic kidney disease not on dialysis: results of randomized clinical trial. Clin J Am Soc Nephrol. 2008;3:337-47.

10. Marsden PA. Treatment of anemia in chronic kidney disease-strategies based on evidence. $\mathrm{N}$ Engl J Med. 2009;261(21):2089-90.

11. Bakris, George, et al. Prevalence and associations of anemia of CKD: Kidney Early Evaluation Program (KEEP) and National Health and Nutrition Examination Survey (NHANES) 1999-2004. .American Journal of Kidney Diseases. 2008;5: S46-S55.

12. Hoffbrand AV, Petit JE, Mos PAH, Essential hematology. Edisi ke-4. Oxford: Blackwell science; 2001.

13. Pranawa. Anemia pada gagal ginjal kronik. Surabaya: Majalah IImu Penyakit Dalam. 1993;4:51-5. 